\title{
STUDI TENTANG TINGKAT PENGETAHUAN ILMU GIZI SISWA-SISWI SMP NEGERI 32 PADANG
}

\author{
Hilmainur Syampurma
}

Program Studi Pendidikan Jasmani Kesehatan dan Rekreasi, Fakultas Ilmu Keolahrgaan Universitas Negeri Padang.Jalan Prof.Dr.Hamka Air Tawar Barat, Padang, 25132, Indonesia.

\section{Email : hilmainursyam@fik.unp.ac.id}

\begin{abstract}
Abstrak
Masalah dalam penelitian ini dilihat dari pekerjaan orang tua siswa rata-rata bertani,dan jam kerja mereka bahkan lebih dari 12 jam sehari. Karena kesibukan yang dialami oleh orang tua tersebut untuk memenuhi kebutuhan hidup, maka timbul kebiasaan yaitu orang tua kurang memperhatikan asupan gizi anaknya, misalnya anak-anaknya tidak dibiasakan untuk sarapan pagi, hanya diberi uang saku untuk membeli makanan di sekolah, membiasakan mengkonsumsi makanan yang dijual di warung, sementara keseimbangan gizi dan kebersihannya kurang diperhatikan. Penelitian ini bertujuan untuk mengetahui dan memaparkan Pengetahuan Ilmu Gizi Siswa-siswi SMP Negeri 32 Padang. Jenis penelitian ini adalah deskriptif, populasi dalam penelitian ini adalah seluruh siswa-siswi SMP Negeri 32 Padang. Penarikan sampel dengan teknik Purposive Sampling, ditetapkan sebanyak 72 orang sebagai sampel. Teknik pengambilan data pengetahuan ilmu gizi dengan membagikan angket. Teknik analisis data yaitu dengan menggunakan distribusi frekuensi (statistik deskriptif) dengan perhitungan persentase. Berdasarkan hasil penelitian diperoleh bahwa Pengetahuan Ilmu Gizi Siswa-Siswi SMP Negeri 32 Padang mencapai persentase $73,24 \%$. Dengan demikian, pengetahuan ilmu gizi siswa-siswi di SMP Negeri 32 Padang dikategorikan "BAIK".
\end{abstract}

Kata Kunci : Pengetahuan Ilmu Gizi

\section{STUDY ABOUT THE LEVEL OF KNOWLEDGE OF NUTRITIONAL SCIENCE STUDENTS SMP NEGERI 32 PADANG}

\begin{abstract}
The problem in this study is seen from the work of parents on average farming students, and their working hours even more than 12 hours a day. Because of the busyness experienced by the parents to fulfill their daily needs, a habit arises that parents pay less attention to their child's nutritional intake, for example their children are not accustomed to breakfast, are only given pocket money to buy food at school, get used to consuming food sold in stalls, while the balance of nutrition and hygiene is less noticed. This study aims to determine and describe and knowledge of nutrition science of students at 32 Junior High School Padang. This type of research is descriptive,the population of this study was all students of 32nd Junior High School Padang. The sampling technique is done by purposive sampling technique, so that as many as 72 people were set as samples. The data collection technique as for nutrition knowledge by distributing questionnaires. Data analysis technique are using descriptive statistics. The following are the result of the study is Knowledge of nutrition in 32 Junior High School Padang students get a percentage 73,24\%. Thus it was concluded that the knowledge of nutrition in students at 32 Junior High School Padang was categorized as "GOOD".
\end{abstract}

Keywords : Knowledge of nutrition

\section{PENDAHULUAN}

Pendidikan merupakan salah satu

bagian terpenting dalam kehidupan manusia. Melalui pendidikan, manusia akan memiliki berbagai ilmu pengetahuan yang berguna bagi kelangsungan hidupnya, baik bagi dirinya sendiri maupun bagi lingkungannya. Dengan pendidikan juga, bangsa ini dapat berkembang menjadi bangsa yang bermartabat dan maju 
diberbagai bidang baik di tingkat nasional maupun internasional. Dengan cara meningkatkan kualitas generasi bangsa, mendidik kepribadian dan karakter peserta didik, serta menumbuh kembangkan potensi-potensi bawaan, baik jasmani maupun rohani, agar sesuai dengan nilainilai yang ada di dalam masyarakat dan kebudayaan. Hal ini sesuai dengan fungsi dan tujuan Pendidikan Nasional dalam Undang-Undang No. 20 Tahun 2003 tentang Sistem Pendidikan Nasional, dalam Bab II Pasal 3 yang menyatakan bahwa :

"Pendidikan nasional berfungsi mengembangkan kemampuan dan membentuk watak serta peradaban bangsa yang bermartabat dalam rangka mencerdaskan kehidupan bangsa, bertujuan untuk berkembangnya potensi peserta didik agar menjadi manusia yang beriman dan bertakwa kepada Tuhan Yang Maha Esa, berakhlak mulia, sehat, berilmu, cakap, kreatif, mandiri dan menjadi warga negara yang demokratis serta bertanggungjawab"

Berdasarkan uraian di atas, maka dapat dijelaskan bahwa tujuan pendidikan pada dasarnya adalah meningkatkan kualitas sumber daya manusia. Melalui peningkatan mutu pendidikan diupayakan tercapainya pembentukan profil manusia yang siap secara intelektual, mental, fisik dan rohani demi menghadapi masa depan yang semakin membutuhkan ilmu pengetahuan dan teknologi. Kemudian untuk mencapai itu sangat diperlukan dan dibutuhkan sekali individu yang sehat, segar jasmani dan rohaninya. Salah satu yang perlu diperhatikan adalah pengetahuan tentang gizi siswa sebagai cerminan bagi siswa dalam memenuhi kecukupan gizi atau tolak ukur yang penting untuk menilai keadaan pertumbuhan dan status kesehatannya.

Dengan adanya pengetahuan tentang gizi akan berdampak pada status gizi yang dimiliki siswa. Status gizi adalah keadaan tubuh sebagai akibat konsumsi makanan dan penggunaan zat-zat gizi (Syafrizar dan Wilda, 2008). Status gizi juga dapat diartikan indikator baik buruknya penyediaan makanan sehari-hari. Status gizi dipengaruhi oleh konsumsi makanan dan penggunaan zat-zat gizi di dalam tubuh.

Faktor yang secara langsung mempengaruhi status gizi adalah asupan makan dan penyakit infeksi. Berbagai faktor yang melatar belakangi kedua faktor tersebut misalnya faktor ekonomi, keluarga, produktifitas dan pengetahuan tentang gizi anak tersebut (Suhardjo, 2003). Masalah gizi seimbang di Indonesia masih merupakan masalah yang cukup berat. Pada hakikatnya berpangkal pada keadaan ekonomi yang kurang dan terbatasnya pengetahuan tentang gizi (Irianto, 2007).

Usia remaja (10-19) tahun biasanya sangat rentan terhadap masalah gizi, karena pada usia remaja banyak mengalami perubahan secara hormonal dan berpengaruh pada perubahan fisiknya, pertumbuhan fisik menyebabkan remaja membutuhkan asupan nutrisi yang lebih besar dari pada anak-anak. Ditambah lagi pada masa ini, remaja sangat aktif dengan berbagai kegiatan, baik itu kegiatan sekolah maupun olahraga. Pengetahuan seseorang, remaja utamanya dipengaruhi oleh pendidikan.

Kurangnya pengetahuan gizi dapat mengakibatkan, ketidakteraturan perilaku dan kebiasaan makan dapat menjadi penyebab terjadinya masalah gizi (Notoadmojo, 2005). Seperti yang telah dijelaskan diatas bahwa status gizi dan pengetahuan ilmu gizi merupakan hal yang penting diketahui oleh siswa dalam kehidupannya untuk melakukan aktivitas sehari-hari, salah satunya adalah dalam kegiatan pembelajaran penjasorkes. Untuk itu asupan zat-zat gizi haruslah terpenuhi agar proses pembelajaran dan aktivitas lainnya dapat berjalan dengan baik dan sesuai harapan.

SMP Negeri 32 Padang adalah salah satu sekolah negeri yang berada di Kota padang, terletak di Jl. Sungai Lareh, Kec. Koto Tangah, Kota Padang. Secara geografis merupakan sekolah yang terletak di tepi bukit dan cukup jauh dari pusat kota. Penduduk wilayah Sungai Lareh mayoritas bermata pencaharian sebagai buruh tani maupun pedagang di pasar. Mereka bekerja setiap hari dalam waktu kurang lebih 12 jam. Karena kesibukan yang dialami oleh 
orang tua, maka timbul kebiasaan yaitu orang tua kurang memperhatikan asupan gizi anaknya. Berdasarkan observasi yang peneliti lakukan di SMP Negeri 32 Padang, bahwasanya pada saat mengikuti kegiatan pembelajaran penjasorkes, banyak diantara siswa tampak kurang bersemangat, lesu, kurang konsentrasi dan malas mengikuti pembelajaran penjasorkes. Seperti yang terlihat selama peneliti dilapangan, siswa sering mengkonsumsi makanan cepat saji dan minum minuman berwarna. Jika hal ini dibiarkan, akan berdampak terhadap proses pertumbuhan dan perkembangan fisik anak, tingkat kesehatan, kebugaran, status gizi bahkan secara tidak langsung juga dapat mempengaruhi hasil belajar dan prestasi siswa di sekolah. Dalam jangka panjang masalah gizi dapat mempengaruhi perkembangan kognitif dan sosial seorang anak serta kemampuannya melakukan aktivitas fisik. Jadi, dari beberapa gejala yang terlihat di lapangan maka masalah yang terlihat yaitu belum diketahuinya status gizi dan tingkat pengetahuan ilmu gizi siswa-siswi SMP Negeri 32 Padang. Menurut Irianto, (2007:2),

Istilah gizi berasal dari bahasa Arab yaitu "giza" yang berarti zat makanan, dalam bahasa inggris dikenal dengan istilah "nutrition" yang berarti bahan makanan atau zat gizi sering diartikan sebagai ilmu gizi". Sedangkan menurut Sutarto (2012:12), "Gizi adalah zat makanan yang diperlukan tubuh yang terdiri dari ; 1) karbohidrat atau hidrat arang, 2) lemak, 3) protein, 4) mineral, 5) vitamin-vitamin, dan 6) air.

Selanjutnya, Proverawati dan Kusumawati (2011:01) menyatakan bahwa gizi berasal dari bahasa Arab yaitu "Ghidza". Gizi adalah suatu proses penggunaan makanan yang dikonsumsi secara normal oleh suatu organisme proses digesti, absorpi, transortasi, penyimpanan, metabolisme, dan pengeluaran zat-zat yang digunakan untuk mempertahankan kehidupan, pertumbuhan dan fungsi normal dari organ-organ, serta menghasilkan energi
Jadi, berdasarkan beberapa kutipan di atas maka dapat disimpulkan bahwa gizi merupakan zat-zat yang ada dalam makanan yang diperlukan oleh tubuh sehingga tubuh memperoleh energi yang dapat digunakan untuk menjalani aktivitas sehari-hari, zat-zat tersebut seperti karbohidrat, lemak, protein, mineral, vitamin dan air. Selain itu gizi dapat diartikan juga sebagai suatu proses penyerapan, maupun pengeluaran zat gizi untuk mempertahankan kehidupan, pertumbuhan dan fungsi normal organ tubuh serta menghasilkan tenaga.

Gizi adalah zat atau elemen yang terkandung di dalam makanan dan dapat dimanfaatkan secara langsung oleh tubuh seperti halnya karbohidrat, protein, lemak, vitamin, mineral dan air. Begitupun dengan gizi yang seimbang dibutuhkan oleh tubuh terlebih pada anak-anak dan remaja yang masih dalam masa pertumbuhan dan perkembangan. Dimasa tumbuh kembang remaja yang berlangsung secara cepat dibutuhkan makanan dengan kualitas dan kuantitas yang tepat dan seimbang.

Menurut pakar gizi Harry Oxorn dan William R.Forte dalam Triwibowo dan Pusphandani (2015:70), "Gizi meliputi pengertian yang luas, tidak hanya mengenai jenis-jenis pangan dan gunanya bagi badan melainkan juga cara mengenai cara-cara memperoleh serta mengolah dan mempertimbangkannya agar kita tetap sehat"

Jadi, dari kutipan diatas dapat dipahami bahwa pengertian gizi tidak saja mengenai jenis makanan yang dibutuhkan oleh tubuh manusia dan fungsinya tetapi juga bagaimana cara mendapatkan makanan tersebut, apakah baik dan bisa dikonsumsi serta cara menyajikannya dan juga mempertimbangkan manfaat dari 
makanan yang dikonsumsi dan tidak membahayakan bagi tubuh dan membuat tubuh menjadi sehat.

Menurut Lioni Ellis $\mathrm{H}$, dalam Triwibowo dan Pusphandani, (2015:70), "Gizi merupakan komponen penting yang diperlukan oleh tubuh dan berkembang. Lebih lanjut Joyce James, dkk menyatakan bahwa gizi adalah komponen kimia dalam makanan yang digunakan untuk tubuh sebagai sumber energi dan membantu pertumbuhan, perbaikan, perawatan sel-sel tubuh.

Jadi, dari beberapa kutipan diatas dapat disimpulkan bahwa gizi merupakan suatu proses organisme mengggunakan makanan yang dikonsumsi secara normal melalui proses absorpsi, transportasi, penyimpanan, metabolisme dan pengeluaran zat-zat yang tidak digunakan, untuk mempertahankan kehidupan, pertumbuhan dan fungsi normal dari organ-organ, serta menghasilkan energi. Notoadmodjo,

menyatakan bahwa pengetahuan adalah hasil dari tahu, dan ini terjadi setelah orang melakukan penginderaan terhadap suatu objek tertentu. Penginderaan terjadi melalui panca indra manusia. Yakni indra penglihatan, pendengaran, penciuman dan raba. Sebagian besar pengetahuan manusia diperoleh melalui mata dan telinga. Pengetahuan atau kognitif merupakan dominan yang sangat penting dalam membentuk tindakan seseorang (over behavior).

Sedangkan

Purwodarminto

(1996:

menurut

"Pengetahuan adalah sesuatu yang diketahui berkaitan dengan proses pembelajaran. Proses pembelajaran ini dipengaruhi berbagai faktor dari dalam seperti motivasi dan faktor dari luar berupa sarana informasi yang tersedia serta keadaan sosial budaya. Secara garis besar domain tingkat pengetahuan mempunyai 6 tingkatan, meliputi: mengetahui, memahami, menggunakan, menguraikan, menyimpulkan, dan mengevaluasi". Ciri pokok dalam taraf pengetahuan adalah ingatan tentang sesuatu yang diketahuinya baik melalui pengalaman, belajar, ataupun informasi yang diterima dari orang lain.

Menurut Soekidjo Notoatmodjo (2007: 140-142) pengetahuan dibagi menjadi 6 (enam) tingkat, yaitu:

1) Tahu (know)

Tahu diartikan sebagai mengingat suatu materi yang telah dipelajari sebelumnya. Disebut juga dengan istilah recall (mengingat kembali) terhadap sesuatu yang spesifik terhadap suatu beban yang dipelajari atau rangsangan yang telah diterima.

\section{2) Memahami}

Memahami diartikan sebagai suatu kemampuan untuk menjelaskan secara benar tentang objek yang diketahui, dan dapat menginterpresentasikan materi tersebut secara benar.

3) Aplikasi

Aplikasi diartikan sebagai kemampuan untuk menggunakan materi yang telah dipelajari pada situasi atau kondisi real (sebenarnya). Aplikasi ini dapat diartikan aplikasi atau penggunaan hukum, rumus, metode, prinsip, dan sebagainya dalam konteks atau situasi yang lain.

4) Analisis

Analisis adalah suatu kemampuan untuk menjabarkan materi atau objek ke dalam komponen-komponen, tetapi masih didalam suatu struktur organisasi, dan masih ada kaitannya satu sama lain.

5) Sintesis

Sintesis menunjukan kepada suatu kemampuan untuk menghubungkan bagian-bagian didalam suatu bentuk keseluruhan yang baru atau kemampuan menyusun formulasi baru dari formulasi-formulasi yang ada. 


\section{6) Evaluasi}

Evaluasi berkaitan dengan masalah kemampuan untuk melakukanterhadap suatu materi objek berdasarkan kriteria yang ditentukan sendiri atau kriteria yang telah ditentukan atau telah ada.

Jadi, berdasarkan uraian di atas dapat diartikan bahwa pengetahuan merupakan hasil dari proses mencari tahu, dari yang tadinya tidak tahu menjadi tahu. Dalam proses mencari tahu ini mencakup berbagai metode dan konsep-konsep baik melalui proses pendidikan, belajar, informasi dari orang lain maupun dari pengalaman.

Ilmu gizi adalah ilmu dan seni yang berkaitan dengan seluk beluk makanan dalam hubungannya dengan kesehatan tubuh manusia. Menurut Kamus Gizi Indonesia yang dikeluarkan oleh Persatuan Ahli Gizi Indonesia (PERSAGI), 2009, "Ilmu Gizi adalah ilmu pengetahuan yang membahas sifatsifat gizi yang terkandung dalam makanan, pengaruh metabolismenya serta akibat yang timbul bila terdapat kekurangan atau kekurangan zat gizi.

Menurut Bogert dalam Syafrizar dan Welis (2008:2), "Ilmu gizi adalah ilmu yang mempelajari tentang pemberian makanan kepada tubuh setepat-tepatnya untuk pertumbuhan, pemeliharaan dan perbaikan". Sedangkan WHO mengartikan ilmu gizi sebagai ilmu yang mempelajari proses yang terjadi pada organisme hidup untuk mengambil makanan dan mengolah zat-zat padat dan cair dari makanan yang diperlukan untuk memelihara kehidupan, pertumbuhan, berfungsinya organ tubuh dan menghasilkan energi.

Sementara itu Riyadi dalam Syafrizar (2009:1) mengatakan ilmu gizi adalah cabang ilmu yang mempelajari hubungan antara makanan yang dimakan dengan kesehatan tubuh yang diakibatkannya serta faktor-faktor yang mempengaruhinya.

Jadi, dari kutipan diatas dapat disimpulkan bahwa ilmu gizi didefinisikan sebagai suatu cabang ilmu yang mempelajari zat-zat pangan yang bermanfaat bagi kesehatan dan proses yang terjadi pada pangan sejak dikonsumsi, dicerna, diserap sampai dimanfaatkan tubuh serta dampaknya terhadap pertumbuhan, perkembangan dan kelangsungan hidup manusia serta faktor yang mempengaruhinya.

Menurut Altmatsier (2002:4), "Pengetahuan gizi adalah sesuatu yang diketahui tentang makanan dalam hubungannya dengan kesehatan optimal. Pengetahuan gizi meliputi pengetahuan tentang pemilihan dan konsumsi sehari-hari dengan baik dan memberikan semua zat gizi yang dibutuhkan untuk fungsi normal tubuh". Zat gizi yang cukup dapat dipenuhi oleh seseorang sesuai dengan makanan yang dikonsumsi yang diperlukan untuk meningkatkan pertumbuhan. Pengetahuan gizi dapat memberikan perbaikan gizi pada individu maupun masyarakat.

Sedangkan Notoatmodjo (2003: 98) menyatakan bahwa pengetahuan gizi merupakan pengetahuan tentang makanan dan zat gizi, sumber-sumber zat gizi pada makanan, makanan yang aman dikonsumsi sehingga tidak menimbulkan penyakit dan cara mengolah makanan yang baik agar zat gizi dalam makanan tidak hilang serta bagaimana hidup sehat. Selanjutnya, menurut Emilia, E (2008), "Pengetahuan gizi adalah kemampuan seseorang untuk mengingat kembali kandungan gizi makanan serta kegunaan zat gizi tersebut dalam tubuh. Pengetahuan gizi ini mencakup proses kognitif yang dibutuhkan untuk menggabungkan informasi gizi dengan perilaku makan, agara struktur 
pengetahuan yang baik tentang gizi dapat dikembangkan.

Jadi, dari beberapa kutipan diatas dapat disimpulkan bahwa pengetahuan gizi merupakan sesuatu yang diketahui tentang makanan dan menyangkut pengetahuan seseorang tentang zat-zat gizi yang ada dalam makanan, cara mengolah bahan makanan agar makanan tersebut tidak banyak kehilangan zat gizi yang terkandung didalamnya dan cara mengolah makanan agar tetap aman dikonsumsi sehingga tidak menimbulkan penyakit, serta pemilihan makanan yang baik untuk dikonsumsi dan cara-cara menjaga tubuh agar tetap sehat melalui pemahaman gizi yang dimiliki seseorang.

Pengetahuan gizi sangat penting bagi setiap orang, sebagaimana yang diungkapkan Suhardjo (1986:31) menyatakan bahwa pengetahuan tentang pentingnya gizi dipengaruhi oleh 3 kenyataan, yaitu:

"(a) setiap gizi yang cukup adalah pentingnya bagi kesehatan dan kesejahteraan, (b) setiap orang hanya akan cukup jika makanan yang dimakan mampu menyediakan zat gizi yang diperlukan untuk pertumbuhan tubuh yang optimal, pemeliharaan dan energi. (c) gizi memberikan fakta-fakta yang perlu sehingga penduduk dapat belajar dengan menggunakan pangan dengan lebih baik bagi kesejahteraan gizi”

Jadi, dari kutipan diatas dapat disimpulkan bahwa pengetahuan tentang gizi sangat penting bagi setiap orang. Dengan pengetahuan gizi, seseorang dapat menjaga tubuh agar tetap sehat sehingga dapat meningkatkan kesejahteraannya. Dengan pengetahuan gizi pula, seseorang akan mengkonsumsi makanan yang mengandung zat gizi yang berguna untuk pertumbuhan tubuh yang optimal dan juga sebagai energi yang dapat digunakan untuk menjalankan aktivitas sehari-hari seperti belajar dan lain sebagainya. Dan dengan pengetahuan gizi pula masyarakat dapat belajar dan juga mengembangkan pangan sehingga dapat digunakan lebih baik lagi untuk meningkatkan kesejahteraan bagi setiap orang. Menurut Almatsier

Pengetahuan gizi meliputi:

"Pengetahuan tentang pemilihan dan konsumsi sehari-hari dengan baik dan memberikan semua zat gizi yang dibutuhkan untuk fungsi normal tubuh. Pemilihan dan konsumsi bahan makanan berpengaruh terhadap status gizi seseorang. Status gizi baik atau status gizi optimal terjadi apabila tubuh memperoleh cukup zat gizi yang dibutuhkan tubuh. Status gizi kurang terjadi apabalia tubuh mengalami kekurangan satu atau lebih zat gizi essential. Sedangkan status gizi lebih terjadi apabila tubuh memperoleh zat gizi dalam jumlah yang berlebihan, sehingga menimbulkan efek yang membahayakan"

Jadi, dari uraian diatas dapat disimpulkan bahwa, semakin tinggi pengetahuan gizi seseorang akan semakin memperhitungkan jenis dan makanan yang dipilih untuk dikonsumsi. Orang yang pengetahuan gizinya rendah akan berprilaku memilih makanan yang menarik panca indera dan tidak mengadakan pemilihan berdasarkan nilai gizi makanan. Sebaliknya mereka yang semakin tinggi pengetahuannya, lebih banyak mempergunakan mempertimbangkan rasional dan pengetahuan tentang nilai gizi makanan tersebut.

\section{Makanan Jajanan}

Menurut Keputusan Menteri Kesehatan Republik Indonesia No. 942/MENKES/SK/VII/2003,

"Makanan jajanan adalah makanan 
dan minuman yang diolah oleh pengrajin makanan di tempat penjualan dan atau disajikan sebagai makanan siap santap untuk dijual bagi umum selain yang disajikan jasa boga, rumah makan atau restoran dan hotel".

Sedangkan menurut FAO dalam Judarwanto (2008), "Makanan jajanan didefinisikan sebagai makanan dan minuman yang dipersiapkan dan dijual oleh pedagang kaki lima di jalanan dan di tempat-tempat keramaian umum lain yang langsung dimakan atau dikonsumsi tanpa pengolahan atau persiapan lebih lanjut"

Jadi, dari beberapa kutipan diats dapat disimpulkan bahwa makanan jajanan adalah makanan dan minuman yang dibuat oleh pengrajin makanan dan dijual ditempat keramaian seperti pasar, lingkungan sekolah dan lain sebagainya dan dapat dimakan secara langsung.

Selanjutnya, menurut Direktorat Perlindungan Konsumen, (2006), "Pangan jajanan termasuk dalam kategori pangan siap saji yaitu makanan dan minuman yang dijual untuk langsung dikonsumsi tanpa proses pengolahan lebih lanjut. Ragam pangan jajanan antara lain: bakso, mie goreng, nasi goreng, ayam goreng, burger, cake, cilok, cireng, cimol, tahu, gulali, es jepit, es lilin dan ragam pangan jajanan lainnya".

Jadi, dari kutipan diatas dapat disimpukan bahwa pangan jajanan adalah makanan siap saji yang sering dijumpai baik dalam bentuk makanan ataupun minuman yang dijual oleh seseorang yang dalam penyajiannya dilakukan secara langsung tanpa pengolahan lebih lanjut. Makanan ini dapat berupa bakso, batagor, gorengan, es lilin, pop ice dan ragam pangan jajanan lainnya.
Makanan Jajanan yang Aman

Menurut Direktorat

Perlindungan Konsumen (2006),

"Pangan jajanan yang seahat dan aman adalah pangan jajanan yang bebas dari bahaya fisik, cemaran bahan kimia dan bahaya biologis".

Jadi, dari kutipan diatas dapat disimpulkan bahwa pangan jajanan yang sehat dan aman adalah pangan yang di dalamnya tidak terkandung bahaya fisik yang dapat berupa benda asing seperti, batu/kerikil, kaca, rambut maupun benda fisik lainnya. Terbebas dari bahaya kimia seperti: pengawet, pewarna kain, pemanis buatan. Cairan pembersin, borak, cat, pestisida dan lainnya dan juga terbebas dari bahaya biologis yang disebabkan oleh bakteri, jamur dan lainnya.

Selanjutnya, menurut Soekirman (2000), "Makanan jajanan aman adalah makanan sehat yang mengandung zat gizi yang cukup dan seimbang juga harus aman, yaitu bebas dari bakteri, virus, parasit, serta bebas dari pencemaran zat kimia. Makanan dikatakan aman apabila kecil kemungkinan atau sama sekali tidak mungkin menjadi sumber penyakit atau yang dikenal sebagai penyakit yang bersumber dari makanan (foodborne disease)".

Jadi, dapat disimpulkan bahwa makanan jajanan yang aman adalah makanan yang terbebas dari zat berbahaya yang dapat menyebabkan penyakit jika dikonsumsi oleh tubuh. Makanan yang sehat harus dipersiapkan, diolah, disimpan, dan disajikan dengan serba bersih dan telahn dimasak dengan benar, sehingga makanan tersebut aman untuk dikonsumsi.

Untuk itu kita harus mengetahui cara untuk memilih pangan dan jajanan yang aman, sebagaimana diungkapkan oleh Direktorat 
Perlindungan Konsumen (2006), "Adapun kiat memilih pangan jajanan yang sehat dan aman yaitu:

1) Hindari pangan yang dijual di tempat terbuka, kotor dan tercemar, tanpa penutup dan tanpa kemasan.

2) Beli pangan yang dijual di tempat bersih dan terlindung dari matahari, debu, hujan, angin dan asap kendaraan bermotor. Pilih tempat yang bebas dari serangga.

3) Hindari pangan yang dibungkus dengan kertas bekas atau koran. Belilah pangan yang dikemas dengan kertas, plastil atau kemasan lain yang bersih dan aman.

4) Hindari pangan yang mengandung bahan pangan sintetis berlebihan atau bahan tambahan pangan terlarang dan berbahaya.

5) Warna makanan atau minuman yang terlalu menyolok, besar kemungkinan mengandung pewarna sintetis, jadi sebaiknya jangan dibeli.

6) Untuk rasa, jika terdapat rasa yang menyimpang, ada kemungkinan pangan mengandung bahan berbahaya atau bahan tambahan pangan yang berlebihan.

Jadi, dari kutipan diatas dapat disimpulkan bahwa terdapat beberapa cara dan kiat untuk memilih pangan dan jajanan yang sehat yaitu dengan menghindari makanan yang dijual di tempat terbuka, berdebu atau dicemari oleh asap kendaraan, pilihlah makanan dengan warna yang tidak terlalu mencolok dan dengan rasa yang tidak menyimoang dari rasa aslinya serta membiasakan diri untuk membeli makanan di tempat bersih yang terhindar dari lalat ataupun serangga lainnya. Dengan begitu makanan yang kita makan termasuk pangan jajanan yang sehat.

\section{Makanan Sehat}

Menurut Syafrizar dan Welis (2008:3), "Makanan adalah bahan selain obat yang mengandung zat-zat gizi dan unsur-unsur/ikatan kimia yang dapat diubah menjadi zat gizi oleh tubuh, yang berguna bila dimasukkan tubuh".

Jadi, dari kutipan diatas dapat disimpulkan bahwa makanan adalah suatu bahas yang selain dari obat yang mengandung zat-zat gizi seperti karbohidrat, lemak, protein, mineral, vitamin dan air. Bahan makanan ini dapat berupa buah, sayur, daging, beras, susu, telur, tempe dan lain sebagainya yang apabila dikonsumsi dapat berfungsi bagi tubuh manusia seperti untuk menghasilkan tenaga, pertumbuhan maupun perbaikan fungsi normal dari organ tubuh manusia.

Makanan yang sehat yaitu makanan yang memiliki beberapa kriteria. Menurut Irianto, Djoko Pekik (2007:140), "Kriteria makanan sehat berimbang meliputi : 1) cukup kuantitas, 2) proporsional, 3) cukup kualitas, 4) sehat/higienis, 5) makanan segar alami (bukan suplemen), 6) makanan golongan nabati lebih menyehatkan dibandingkan dengan hewani 7) cara memasak jangan berlebihan, 8) teratur dalam penyajian, 9) frekuensi 5 kali sehari, 10) minumlah 6 gelas air sehari.

Jadi, dari uraian diatas dapat disimpulkan bahwa kriteria makanan sehat yaitu makanan yang dikonsumsi sesuai dengan kebutuhan dengan jenis lama aktivitas, berat badan, jenis kelamin dan usia. Jumlah makanan yang dikonsusmsi sesuai dengan proporsi makanan sehat berimbang. Tidak sekedar membuat perut kenyang, tetapi juga berpengaruh terhadap pertumbuhan tubuh. Selain itu makanan harus steril, bebas dari kuman penyakit sehingga makanan aman untuk dikonsumsi.

Irianto (2007:140) menyatakan bahwa untuk mendapatkan makanan 
yang berkualitas dalam jumlah yang cukup, selain memperhatikan kriteria makanan sehat, perlu juga mempertimbangkan 13 pesan dasar makanan sebagai berikut:

1) Beragam

2) Cukup energi

3) Karbohidrat $1 / 2$ dari energi

4) Lemak 1/4 dari energi

5) Gunakan garam beryodium

6) Makanan sumber zat besi

7) ASI hingga usia 4 bulan (bayi)

8) Biasakan sarapan

9) Cukup minum air

10) Imbangi berolahraga

11) Hindari rokok dan alkohol

12) Pilih makan sehat

13) Baca label kemasan (lihat tanggal kadaluwarsa).

\section{METODE}

Penelitian ini bersifat deskriptif yang bertujuan untuk mengungkapkan dan mendeskripsikan suatu keadaan pada saat penelitian dilakukan. Menurut Arikunto (2010) penelitian deskriptif adalah "penelitian yang berusaha mendekripsikan suatu gejala kejadian dimasa sekarang atau dengan perkataan lain peneliti terhadap masalah-masalah aktual sebagaimana adanya saat penelitian dilakukan". Di dalam penelitian ini nantinya akan diungkapkan bagaimana status gizi dan tingkat pengetahuan ilmu gizi siswa-siswi di SMP N 32 Padang.

Populasi penelitian ini adalah seluruh siswa-siswi SMP N 32 Padang yang berjumlah 524. Penarikan sampel menggunakan teknik Purposive sampling yaitu yang sesuai dengan tujuan yang diinginkan oleh peneliti berdasarkan pertimbangan-pertimbangan tertentu, sehingga ditetapkan sebanyak $20 \%$ dari keseluruhan populasi yang berjumlah 72 orang. Instrumen penelitian menggunakan instrumen staturemeter dan timbangan untuk status gizi dan angket dengan skala guttman untuk pengetahuan ilmu gizi. Data dianalisis secara deskripif melalui rumus persentase.

\section{HASIL DAN PEMBAHASAN}

Setelah data diolah menggunakan rumus persentase deskriptif, maka dapat dijelaskan hasil tingkat pengetahuan gizi siswa-siswi di SMP N 32 Padang adalah sebagai berikut:

\section{a. Pengetahuan Ilmu Gizi Siswa-Siswi}

Hasil analisis Pengetahuan Ilmu Gizi dijabarkan sebagai berikut:

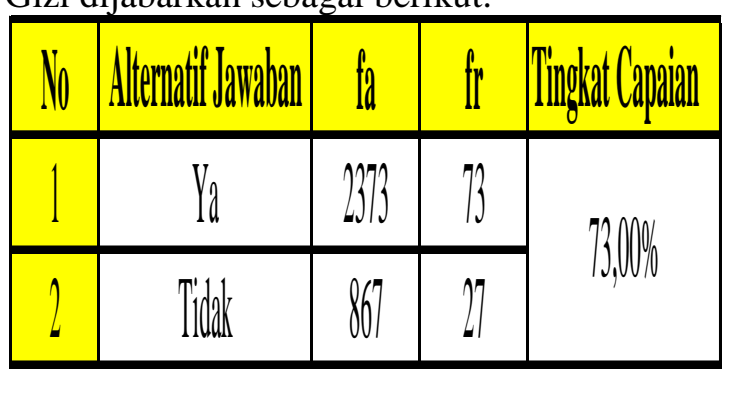

Pada tabel diatas dapat diketahui bahwa hasil pengamatan kepada sampel untuk variabel pengetahuan ilmu gizi siswasiswi SMP N 32 Padang yang menjawab dengan "Ya" sebanyak 73,00\%, dan yang menjawab "Tidak" sebanyak 27,00\%. Berdasarkan hasil diatas, dapat digambarkan melalui histogram berikut :

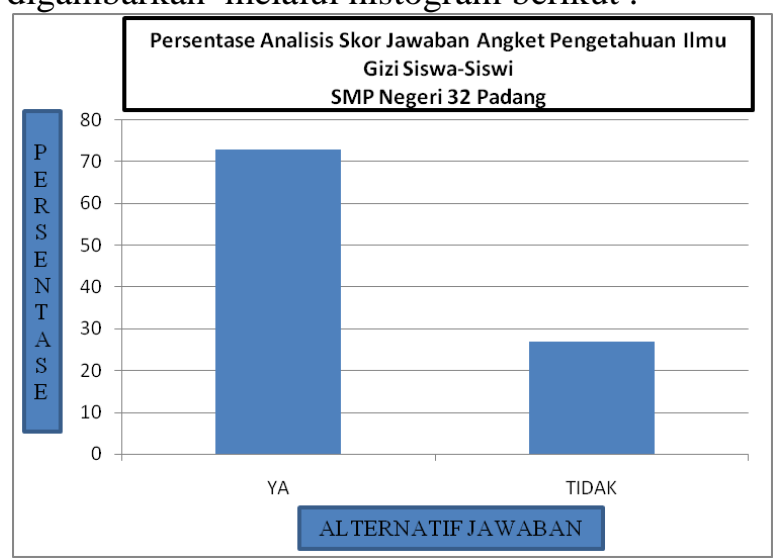

\section{Gambar Diagram Persentase Variabel Pengetahuan Ilmu Gizi}

Berdasarkan hasil pengamatan observer terhadap masing-masing butir lembaran angket didapatkan persentase pengetahuan ilmu gizi mencapai 73,24\%. Dengan demikian, pengetahuan ilmu gizi siswa-siswi di SMP Negeri 32 Padang dikategorikan "BAIK".

\section{PEMBAHASAN}

Berdasarkan analisis yang telah di uraikan diatas, maka dalam bagian ini akan dilakukan pembahasan hasil penelitian mengenai pengetahuan ilmu gizi siswasiswi SMP Negeri 32 Padang. Dari tabel 3 
diketahui bahwa pengetahuan ilmu gizi siswa-siswi di SMP Negeri 32 Padang untuk variabel pengetahuan ilmu gizi siswasiswi SMP N 32 Padang yang menjawab dengan "Ya" sebanyak 73,00\%, dan yang menjawab "Tidak" sebanyak 27,00\%. Artinya tingkat pengetahuan ilmu gizi siswa-siswi SMPN 32 Padang berada pada kategori yang baik.

Dari persentase diatas dapat disimpulkan bahwa pengetahuan ilmu gizi siswa-siswi di SMP Negeri 32 Padang berada pada kategori baik, tetapi masih terdapat juga siswa yang memiliki tingkat pengetahuan ilmu gizi dalam kriteria kurang baik maupun cukup baik saja. Hal ini disebabkan karena jarangnya penyuluhan-penyuluhan gizi yang dilakukan oleh pihak sekolah melalui kegiatan UKS maupun kegiatan penyuluhan dari Puskesmas terdekat. Selain itu, kebiasaan dan faktor lingkungan juga mempengaruhi pengetahuan dan juga status gizi anak. Kemudian, tingkat pendidikan orang tua juga bisa mempengaruhi tingkat pengetahuan anak tentang gizi, karena orang tua adalah orang pertama yang memiliki tanggung jawab untuk memberikan asupan gizi yang seimbang maupun memberikan informasi tentang gizi.

Pengetahuan akan gizi ini sangat penting bagi siswa, sebagaimana yang diungkapkan Suhardjo (1986) pengetahuan tentang pentingnya gizi dipengaruhi oleh 3 kenyataan, yaitu :

“(a) setiap gizi yang cukup adalah pentingnya bagi kesehatan dan kesejahteraan, (b) setiap orang hanya akan cukup jika makanan yang dimakan mampu menyediakan zat gizi yang diperlukan untuk pertumbuhan tubuh yang optimal, pemeliharaan dan energi. (c) gizi memberikan fakta-fakta yang perlu sehingga penduduk dapat belajar dengan menggunakan pangan dengan lebih baik bagi kesejahteraan gizi".

Dari kutipan diatas dapat disimpulkan bahwa pengetahuan ilmu gizi sangat penting bagi setiap orang, termasuk bagi seorang pelajar. Dengan pengetahuan ilmu gizi, siswa dapat menjaga tubuh agar tetap sehat dengan memperhatikan dalam pemilihan makanan yang akan dikonsumsinya. Dengan pengetahuan gizi pula, siswa akan mengkonsumsi makanan yang mengandung zat gizi yang berguna untuk pertumbuhan tubuh yang optimal dan juga sebagai energi yang dapat digunakan untuk menjalankan aktivitas sehari-hari seperti belajar, bermain dan aktivitas fisik lainnya.

Selain itu dapat disimpulkan bahwa pengetahuan ilmu gizi sangat penting bagi setiap orang termasuk bagi seorang pelajar atau siswa. Siswa yang memiliki pengetahuan gizi yang baik akan semakin memperhitungkan jenis makanan yang akan dikonsumsi, dan juga akan pandai memilih makanan yang baik dikonsumsi sehingga dengan begitu akan mempengaruhi status gizinya dalam keadaan yang normal. Siswa yang pandai dalam pemilihan makanan dan asupan gizi nya tentu akan bisa mendapatkan status gizi yang baik. Tetapi, status gizi tidak saja dipengaruhi oleh pengetahuan yang baik, banyak faktor yang menentukan status gizi seseorang, seperti faktor keturunan, gaya hidup maupun lingkungan juga dapat menentukan status gizi seseorang. Siswa yang memiliki keturunan dari orang tua yang gemuk atau kurus tentu dia memiliki resiko untuk menjadi gemuk (obesitas).

\section{KESIMPULAN}

Berdasarkan hasil penelitian dan pembahasan yang telah penulis uraikan diatas, maka dapat diambil kesimpulan sebagai berikut: Pengetahuan Ilmu Gizi Siswa-siswi SMPN 32 Padang memperoleh skor capaian sebesar 2373, maka persentase pengetahuan ilmu gizi siswa-siswi yang meliputi seluruh yang terdapat dalam pengetahuan ilmu gizi mencapai 73,24\%. Dengan demikian, pengetahuan ilmu gizi siswa-siswi di SMP Negeri 32 Padang dikategorikan "BAIK". 


\section{DAFTAR PUSTAKA}

Almatsier, Sunita. 2009. Prinsip Dasar Ilmu Gizi. Jakarta : Gramedia Pustaka Utama

Arikunto, Suharsimi. 2010. Prosedur Penelitian : Suatu Pendekatan Praktek. Jakarta : Rineka Cipta

Dewi, Ayu Bulan Febry Kurnia, dkk. 2013. Ilmu Gizi Untuk Praktisi Kesehatan. Yogyakarta : Graha Ilmu

Irianto, Djoko Pekik. 2007. Panduan Gizi Lengkap Keluarga dan Olahragawan. Yogyakarta: CV Andi Offset

Kemenkes RI. 2011. Keputusan Menteri Kesehatan Republik Indonesia No. 1995/Menkes/SK/XII/2010 tentang Standar Antropometri Penilaian Status Gizi Anak. Jakarta : Direktorat Bina Gizi.

Notoatmodjo, Soekidjo. 2011. Kesehatan Masyarakat Ilmu dan Seni. Jakarta : Rineka Cipta
Suhardjo. 1986. Pangan, Gizi dan Pertanian. Jakarta : UI Press

Syafrizal \& Wilda Wellis. 2008. Gizi Olahraga. Padang: FIK Universitas Negeri Padang

Syampurma, Hilmainur. dkk. 2017. Perbedaan Tingkat Kesegaran Jasmani Berdasarkan Status Gizi. Jurnal Media Ilmu Ke olahragaan Indonesia. Volume 7. Nomor 1 : 2829

Triwibowo, Cecep dan Pusphandani. 2015. Pengantar Dasar Ilmu Kesehatan Masyarakat. Yogyakarta : Nuha Medika.

Undang - Undang Republik Indonesia Nomor 3 Tahun 2005 Tentang Sistem Keolahragaan Nasional.

Zalfendi dkk. 2011. Gizi Olahraga. Padang : Suka Bina Press. 